\title{
HUBUNGAN ANTARA PERGAULAN TEMAN SEBAYA DENGAN \\ MOTIVASI BELAJAR MATA PELAJARAN SEJARAH \\ KEBUDAYAAN ISLAM SISWA KELAS VII MADRASAH \\ TsANAWIYAH (MTs) NEGERI 2 KABUPATEN CIREBON
}

\author{
Muhamad Faizin, A. Syathori, Mahbub \\ Fakultas Ilmu Tarbiyah dan Keguruan \\ Institut Agama Islam Negeri Syekh Nurjati Cirebon \\ Email: faizinm928@gmail.com
}

\begin{abstract}
ABSTRAK
Berdasarkan studi pendahuluan yang dilakuan oleh peneliti pada tanggal 16 November di MTs Negeri 2 KabupatenCirebon ditemukan fenomena yang menarik untuk dipelajari dan diteliti. Yaitu tentang pergaulan teman sebaya di MTs Negeri 2 KabupatenCirebon yang baik, Menurut guru mata pelajaran Sejarah Kebudayaan Islam saat saya wawancarai. Tapi, motivasi belajar kurang antusias dalam mengikuti pelajaran Sejarah Kebudayaan Islam di kelas VII.

Penelitian ini bertujuan untuk mengetahuihubungan yang signifikan antara Pergaulan Teman Sebaya dengan motivasi belajar siswapada bidang studi Sejarah Kebudayaan Islam (SKI) Madrasah Tsanawiyah (MTs) Negeri 2 Kabupaten Cirebon kecamatan Ciwaringin, Kabupaten Cirebon.

Kerangka penelitian ini Pergaulan Teman Sebaya disekolah yang terjadi saat kegiatan belajar mengajar didalam kelas maupun diluar kelas memiliki peranan penting dalam menumbuhkan Motivasi Belajar $(X)$ sebagai variabel bebas dan Motivasi Belajar (Y) sebagai variabel terikat

Penelitian ini merupakan jenis penelitian kuantitatif. Teknik pengumpulan data yang dilakukan dalam penelitian ini antara lain: observasi, wawancara, angket, dan studi dokumentasi. Sedangkan teknik analisis datanya penulis gunakan rumus korelasi product moment. Populasi dalam penelitian adalah seluruh siswa Madrasah Tsanawiyah (MTs) Negeri 2 Kabupaten Cirebon. Adapun yang menjadi sampel adalah kelas VII-B yang berjumlah 50 dengan teknik cluster sampling.
\end{abstract}


Kesimpulan hasil penelitian menunjukkan bahwahubungan antara pergaulan teman sebaya pada bidang Sejarah Kebudayaan Islamdengan motivasi belajar mata pelajaran Sejarah Kebudayaan di Madrasah Tsanawiyah (MTs) Negeri 2 Kabupaten Cirebon tingkat korelasi rendah. Hal ini dapat dibuktikan dari perhitungan koefisien korelasi dengan nilai 0,31 yang berada pada interval 0,200,40Berdasarkan perhitungan uji korelasi " $r$ " product moment dihasilkan nilai $r$ sebesar 0,31 kemudian $r_{\text {hitung }}$ di atas dikonsultasikan ke $r_{\text {tabel }}$ pada df 48 diperoleh $r_{\text {tabel }}$ dengan derajat kepercayaan 0,05 sebesar 0,284. Dengan begitu dapat dikatakan bahwa $r_{\text {hitung }}$ berada di atas $r_{\text {table }}$ maka uji hipotesis menjawab $H_{a}$ diterimadan $H_{0}$ ditolak. Artinya bahwa antara variabel $x$ (pergaulan teman sebaya) dan variabel y (motivasi belajar mata pelajaran Sejarah Kebudayaan Islam) di Madrasah Tsanawiyah (MTs) Negeri 2 Kabupaten Cirebon terdapat hubungan yang signifikan secara statistik. 


\section{PENDAHULUAN}

Pendidikan adalah suatu proses upaya yang dilakukan secara sadar dan sengaja untuk meningkatkan nilai perilaku seseorang atau masyarakat, dari keadaan tertentu ke suatu keadaan yang lebih baik (Taqiyuddin, 2011:70). Di dalam Undang-undang Nomor.20 Tahun 2003 tentang Sistem Pendidikan Nasional Pasal 1 menyebutkan bahwa pendidikan merupakan usaha sadar dan terencana untuk mewujudkan suasana belajar dan proses pembelajaran agar peserta didik secara aktif mengembangkan potensi dirinya untuk memiliki kekuatan sepiritual mulia, serta keterampilan yang diperlukan oleh dirinya, masyarakat, bangsa dan Negara. Hal ini berarti dalam praktik usahanya pendidikan bertujuan untuk mewujudkan suasana belajar yang aktif sehingga dapat meningkatkan segala potensi yang ada dalam diri siswa. Meningkatkan pertumbuhan dan perkembangan siswa dapat dilakukan dengan cara memberikan pengajaran, bimbingan, latihan atau pembiasaan yang diarahkan dalam rangka mengembangkan kepribadian dan kemampuan siswa kearah yang lebih baik.

Belajar merupakan kegiatan yang dilakukan agar seseorang dengan tujuan mendapatkan perubahan perilaku yang berbeda dari sebelumnya. Dalam kegiatan belajar tersebut, seseorang akan memperoleh pengalaman-pengalaman tertentu sebagai hasil interaksi dengan lingkungan. Seseorang akan mengerti mana yang baik untuknya dan mana yang merugikan dirinya, berdasarkan apa yang dialaminya sendiri maupun pengalaman orang lain. Pengalaman inilah yang nantinya akan membentuk pribadi seseorang ke arah kedewasaan (Syaiful Bahri Djamarah, 2012: 22).

Banyak faktor yang mempengaruhi proses belajar. diantaranya motivasi melajar adalah dorongan internal dan eksternal pada siswa-siswa yang sedang belajar untuk mengadakan perubahan tingkah laku, pada umumnya dengan beberapa indikator atau unsur yang mendukung (Hamzah B Uno, 2016: 23) yang dibedakan menjadi dua jenis yaitu motivasi intrinsikbersumber dari dalam diri sendiri dan motivasi ekstrinsik bersumber dari luar diri sendiri diantaranaya di lingkungan sosial, seperti pergaulan teman sebaya. Dalam kelompok sebaya , individu merasakan adanya kesamaan satu sama lain, seperti dibidang usia, kebutuhan, dan tujuan yang dapat memperkuat kelompok itu, sehingga individu 
merasa menemuakan dirinya serta dapat mengembangakan rasa sosialnya sejalan dengan perkembangan kepribadianya (Slamet Santosa, 2009:77). Dalam AlQur'an kita diperintahkan untuk memilih teman yang bertaqwa agar dapat memberikan pengaruh yang baik. Sebagaimana dijelaskan dalam Q.S Zukhruf: 67 berikut ini:

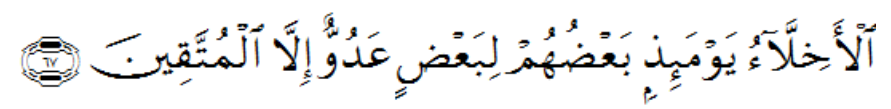

"Teman-teman akrab pada hari itu sebagiannya menjadi musuh bagi sebagian yang lain kecuali orang-orang yang bertakwa."(QS. az-Zukhruf [43]: 67)

Ayat di atas menjelaskan bahwa semua pertemanan dan persahabatan yang bukan kerana Allah subhanallahu wa ta'ala akan menjadi permusuhan pada hari Kiamat, kecuali persahabatan yang dilandasi niat kerana Allah subhanallahu wa ta'ala, sebab persahabatan seperti itu akan kekal selamanya (Syaikh Shafiyyurrahman al-Mubarakfuri, Jilid 8: 233). Adapun Hadits berikut dengan sangat jelas menuntun kita untuk memiliki teman duduk yang baik.

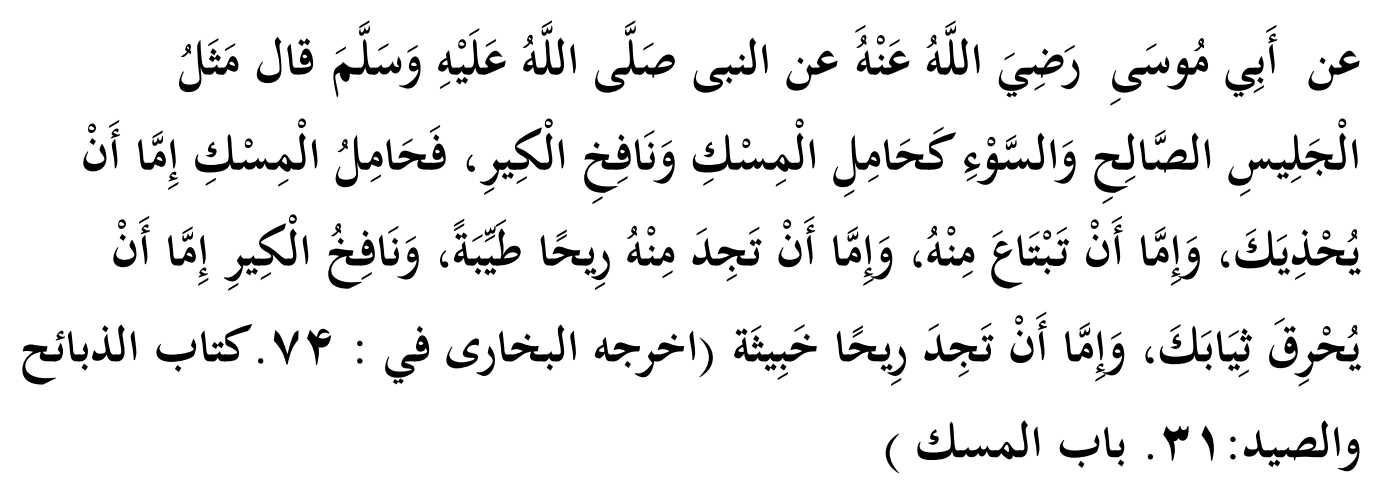

"DariAbu Musa radliallahu 'anhu berkata dari Rasulullah shallallahu 'alaihi wasallam bersabda: "Perumpamaan teman yang shalih dengan teman dengan teman buruk bagaikan penjual minyak wangi denagn tukang pandi besi, bisa jadi penjual minyak wangi itu akan menghadiakan kepadamu atau kamu membeli darinya atau kamu mendapakan bau wanginya sedangkan pandai besi hanyaakan membakar bajumu atau kamu akan mendapatkan bau yang tidak sedap ".(Diriwayatkan oleh Bukhari di dalam kitab ke-72 kitab binatang sembelihan dan buruan, bab ke-31 Bab minyak wangi) 
Lewat pergaulan teman sebaya. Anak-anak menilai apa yang dilakuakan dengan lingkungan teman sebayanya, apakah dia lebih baik, atau sama dengan temannya, ataukah lebih buruk dari pada teman-temannya. Dengan adanya pergaulan diantara siswa maka terbentuk suatu kumpulan yang dapat dijadikan suatu sumber motivasi ekstrinsik, yaitu pergaulan teman sebaya. Kebersamaan dengan waktu lama di sekolah dapat memberikan motivasi tersendiri dalam proses belajar.Faktor-faktor tersebut dapat mendukung dan juga dapat menghambat proses belajar. Semakin banyak faktor pendukung kegiatan belajar, maka semakin besar pula motivasi belajar sesorang.

Dapat dipastikan pergaulan yang baik akan mendorong mereka bergaul yang baik pula. Sebaliknya, pergaulan yang kurang baik akan mendorong seseorang melakukan hal-hal tercela dalam hidupnya. Pengaruh Pergaulan Teman Sebaya disekolah yang terjadi saat kegiatan belajar mengajar didalam kelas maupun diluar kelas memiliki peranan penting dalam menumbuhkan Motivasi Belajar dan meningkatkan keaktifan dan keefektifan belajar. dalam proses belajar, siswa memerlukan keadaan yang menyenangkan, serta minat dan motivasi dalam melakukan kegiatan belajar mengajar agar siswa tidak mudah bosan.

Berdasarkan studi pendahuluan yang dilakuan oleh peneliti pada tanggal 16 November di MTs Negeri 2 Kabupaten Cirebon ditemukan fenomena yang menarik untuk dipelajari dan diteliti. Yaitu tentang pergaulan teman sebaya di MTs Negeri 2 Kabupaten Cirebon yang baik, Menurut guru mata pelajaran Sejarah Kebudayaan Islam saat saya wawancarai. Tapi, motivasi belajar kurang antusias dalam mengikuti pelajaran Sejarah Kebudayaan Islam di kelas VII beberapa siswa terlihat berbicara dengan temanya, ketika guru memberikan suatu pertanyaan tentang Sejarah Kebudayaan Islam siswa tidak menjawab pertanyaan, siswa juga hanya akan belajar jika akan diadakan ulangan atau ujian, hal itu menunjukan bahwa rendahnya motivasi belajar yang dimiliki siswa.

Berdasarkan latar belakang masalah di atas, maka peneliti menurunkan pertanyaan penelitian pada skripsi ini yaitu sebagai berikut : 
1. Apakah Pergaulan Teman Sebaya pada Mata Pelajaran Sejarah Kebudayaan Islam Siswa Kelas VII Di MTs Negeri 2 Kabupaten Cirebon dikategorikan baik?

2. Apakah Motivasi Belajar Siswa pada Mata Pelajaran Sejarah Kebudayaan Islam Siswa Kelas VII Di MTs Negeri 2 Kabupaten Cirebon dikategorikan baik?

3. Adakah hubungan yang signifikan antara Pergaulan Teman Sebaya dengan Motivasi Belajar Siswa Pada Mata Pelajaran Sejarah Kebudayaan Islam Siswa Kelas VII Di MTs Negeri 2 KabupatenCirebon?

Berdasarkan pertanyaan penelitian di atas, maka diperoleh tujuan penelitian sebagai berikut :

1. Untuk mengetahuiPergaulan Teman Sebayapada Mata Pelajaran Sejarah Kebudayaan Islam Siswa Kelas VII Di MTs Negeri 2 Kabupaten Cirebondikategorikan baik?

2. Untuk menilai seberapa besar Motivasi Belajar siswa pada Mata Pelajaran Sejarah Kebudayaan Islam Siswa Kelas VII Di MTs Negeri 2 Kabupaten Cirebon dikategorikan baik

3. Untuk mengetahui hubungan yang signifikan antara Pergaulan Teman Sebaya dengan Motivasi Belajar Siswa Pada Mata Pelajaran Sejarah Kebudayaan Islam Siswa Kelas VII DiMTs Negeri 2 KabupatenCirebon

\section{PEMBAHASAN}

Pergaulan adalah salah satu sisi positif bagi perkembang mentalitas para remaja. Pada fase ini mereka belajar dan mempersiapkan diri menuju fase remaja dewasa dan selanjutnya menjadi orang dewasa. Dapat dipastikan pergaulan yang baik akan mendorong mereka untuk melakukan hal yang baik juga dalam hidup mereka. Sebalikanya, pergaulan yang kurang baik akan mendorong mereka melakukan hal-hal tercela dalam hidup mereka ( E. B. Surbakti; 2009: 306)

Menurut Santrock (2015: 100) teman sebaya adalah anak pada usia yang sama atau pada level kedewasaan yang sama kelompok sebaya merupakan dunia nyata kawula muda, yang menyiapakan panggung dimana ia dapat menguji diri sendiri dan orang lain (Hurlock;1980:214) Teman sebaya pada umumnya adalah 
teman sekolah dan atau teman bermain di luar sekolah (Rita Eka Izzaty; 2008., 114)

kelompok sebaya ini juga merupakan agen sosialisasi yang mempunyai pengaruh kuat searah dengan bertambahnya usia anak (Umar Tirtarahardja; 2005:97) teman sebaya biasanya terdiri dari anak-anak ras, asal etnis, dan status sosial ekonominya. Anak-anak tersebut biasanya berusia sama dan berjenis kelamin yang sama (Lusi Nuryanti; 2008: 68)Dalam kelompok sebaya , individu merasakan adanya kesamaan satu sama lain, seperti dibidang usia, kebutuhan, dan tujuan yang dapat memperkuat kelompok itu, sehingga individu merasa menemuakan dirinya serta dapat mengembangakan rasa sosialnya sejalan dengan perkembangan kepribadianya(Slamet Santosa; 2009:77)

Motivasi adalah perubahan energi dalam diri seseorang yang dengan ditandai dengan timbulnya perasaan dan reaksi untuk mencapai tujuan ( Oemar Hamalik; 2017: 158). Menurut Mc. Donald (1959) dalam Sadirman (2016: 73-74) motivasi adalah perubahan energi dalam diri seseorang yang dengan ditandai dengan munculnya "feeling" dan didahului dengan tanggapan terhadap tujuan. Motivasi adalah daya penggerak/ pendorong untuk melakukan sesuatu pekerjaan( Dalyono; 2015: 57).

Belajar ialah suatu proses usaha yang dilakukan seseorang untuk memperoleh suatu perubahan tingkah laku yang baru secara keseluruhan, sebagai hasil pengalamanya sendiri dalam interaksi dengan lingkunganya (Slameto; 2015: 2) belajar mengandung pengertian terjadinya perubahan dari persepsi dan perilaku, termasuk juga perbaikan perilaku, misalnya pemuasan kebutuhan masyarakat dan pribadi secara lebih lengkap (Oemar Hamalik; 2014: 45) belajar merupakan tindakan siswa yang kompleks ( Dimiyati dan Mujiono; 2015: 7) belajar adalah proses perubahan didalam diri manusia, apabila setelah setelah belajar tidak terjadi perubahan dalam diri manusia, maka tidak dapat dikatakan bahwa padanya telah berlangsung proses belajar.

Motivasi belajar adalah dorongan internal dan eksternal pada siswa-siswa yang sedang belajar untuk mengadakan perubahan tingkah laku, pada umumnya dengan beberapa indikator atau unsur yang mendukung (Hamzah B Uno; 2016: 23). Motivasi belajar merupakan daya gerak psikis dari dalam diri seseorang 
untuk dapat melakukan kegiatan belajar dan menambah keterampilan, pengalaman ( Martinis Yamin; 2012: 80).

Penelitian ini dilaksanakan dan dilakukan di Madrasah Tsanawiah (MTs) Negeri 2 Kabupaten Cirebon yang beralamat di jalan kebon melati No. 02,Desa Babakan, kecamatan Ciwaringin, Kabupaten Cirebon, Jawa Barat, yang berkode pos 45167.

Waktu penelitian ini dilaksanakan tiga bulan, berdasarkan surat keputusan oleh Dekan Fakultas Ilmu Tarbiyah dan Keguruan (FITK) Nomor : 6837/In.08/F.I/PP.009/1111//11/2017 terhitung mulai tanggal 02Oktober sampai dengan 30 Desember 2017. Waktu penelitian dilaksanakan pada semester Ganjil tahun ajaran 2017/2018.

Sumber data teoritik adalah sumber data yang didapat berdasarkan teori tentang permasalahan yang diteliti dengan menggunakan buku-buku perpustakaan (Sugiyono, 2015:52)Dalam hal ini peneliti menggunakan buku-buku yang berkenaan dengan Teman Sebaya dan motivasi belajar.

Sumber data empirik adalah sumber data yang diperoleh dari lapangan penelitian untuk memperoleh data yang lebih konkrit yang berkaitan dengan masalah yang diteliti. (Sugiyono, 2015:52).

Jenis penelitian ini bersifat kuantitatif. Penelitian kuantitatif adalah jenis penelitian yang mengahasilkan penemuan-penemuan yang dapat diperoleh dengan menggunakan prosedur statistik atau dengan cara dari kualifikasi pengukuran. Penelitian kuantitatif banyak menuntut menggunakan angka, mulai dari pengumpulan data, penafsiran terhadap data tersebut, serta penyajian dari analisis datanya (Suharsimi Arikunto, $2016: 10$ )

Populasi adalah wilayah generalisasi yang terdiri dari objek atau subjek yang mempunyai kualitas dan karakteristik tertentu yang diterapkan oleh peneliti untuk dipelajari dan kemudian diambil kesimpulan (Sugiyono, 2015: 117) Populasi pada penelitian ini adalah seluruh siswa kelas VII yang berjumblah 506 siswa Di MTs Negeri 2 Kabupaten Cirebon

Sampel adalah bagian dari jumlah dan karakteristik yang dimiliki oleh populasi tersebut. Jika populasinya besar, dan peneliti tidak mungkin mempelajari semua yang ada pada populasi, maka peneliti dapat menggunakan sampel yang 
diambil dari populasi tersebut sehingga sampel diambil dari populasi benar-benar representatif (mewakili) (Sugiyono, 2015: 118) sampel yang digunakan dalam penelitian ini adalah cluster random sampling.

Adapun teknik sampel yang digunakan adalah teknik cluster sampling. teknik ini digunakan untuk menentukan sampel jika obyek yang akan diteliti atau sumber datanya sangat luas. Teknik sampling (cluster sampling) ini dipergunakan untuk menentukan tingkatan kelas yakni kelas VII dengan pertimbangan dari guru, karena kelas VII ada 11 dan tidak mungkin diteliti semua, maka peneliti Memilih VII B yang berjumlah 50 orang yang menjadi sempel .

Dalam penelitian ini terdiri dari dua variabel, yaitu variabel independen dan variabel dependen.

Variabel Independen,

Dalam bahasa Indonesia disebut sebagai variabel bebas. Variabel bebas merupakan variabel yang mempengaruhi atau yang menjadi sebab perubahannya atau timbulnya variabel dependen (terikat). dalam penelitian ini, maka yang menjadi variabel bebasnya ialah Pergaulan Teman Sebaya atau dalam penelitiannya sering digunakan istilah variabel " $\mathrm{X}$ ".

Variabel Dependen

Dalam bahasa Indonesia sering disebut sebagai variabel terikat. Variabel terikat merupakan variabel yang dipengaruhi atau yang menjadi akibat, karena adanya variabel bebas. Dalam penelitian ini yang merupakan variabel terikat ialah Motivasi Belajar atau dalam penelitiannya sering digunakan istilah variabel "Y". Definisi Konseptual

Menurut santrock (2015: 100) teman sebaya adalah anak pada usia yang sama atau pada level kedewasaan yang sama. Dalam kelompok sebaya, individu merasakan adanya kesamaan satu sama lain, seperti dibidang usia, kebutuhan, dan tujuan yang dapat memperkuat kelompok itu, sehingga individu merasa menemuakan dirinya serta dapat mengembangakan rasa sosialnya sejalan dengan perkembangan kepribadianya( Slamet Santosa, 2009:77)

Motivasi belajar adalah dorongan internal dan eksternal pada siswa-siswa yang sedang belajar untuk mengadakan perubahan tingkah laku, pada umumnya 
dengan beberapa indikator atau unsur yang mendukung (Hamzah B Uno, 2016: 23).

\section{Definisi Operasinal}

pergaulan teman sebaya adalah hubungan interaksi dan sosialisasi yang terbentuk dan tercipta, karena individu-individu berkumpul dan membentuk suatu kelompok sosial yang didasari oleh persamaan usia, jenis kelamin, status sosial, kebutuhan, tujuan. Adapun indikatornya: kerjasama, persaingan, pertentangan, penyesuaian, Perpaduan

motivasi belajar adalah keseluruhan daya gerak baik itu dari luar diri maupun dari dalam diri siswa dengan menciptakan suatu usaha untuk mempersiapkan kondisi tertentu untuk mengarahkan pada kegiatan belajar sehingga tujuanya tercapaiMotivasi Belajar biasanya di tandai dengan indikator :tekun menghadapi tugas, ulet menghadapi tugas, menunjukan minat terhadap bermacam-macam masalah, lebih senang bekerja sendiri, cepat bosan pada tugas-tugas rutin, dapat mempertahankan pendapatnya, tidak mudah melepaskan yang diyakini, senang mencari dan memecahkan masalah.

Teknik Pengumpulan Data

Dalam proses pencarian data, penulis menggunakan beberapa metode pengumpulan data sebagai berikut:

Menurut Suharsimi Arikunto (2016 : 199) observasi atau yang disebut juga dengan pengamatan meliputi kegiatan kegiatan pemuatan perhatian terhadap sesuatu objek dengan menggunakan seluruh alat indra.Jadi, mengobservasi dapat dilakukan melalui penglihatan, penciuman, pendengaran, peraba, dan pengecap. Peneliti mengamati kondisi (gedung, kelas, lingkungan, sarana-prasarana dll di MTs Negeri 2 Kabupaten Cirebon

Dokumentasi digunakan untuk mengambil data penelitian yang bersumber pada benda-benda tertulis, seperti buku-buku, majalah, dokumen, peraturanperaturan, notulen rapat, catatan harian, dan sebaginya (Suharsimi Arikunto, 2016 :201)

Menurut Suharsimi Arikunto (2016: 198) metode interview atau wawancara adalah sebuah dialog yang dilakukan oleh pewawancara (interviewer) untuk memperoleh informasi dari terwawancara. Tujuan dari wawancara ini sendiri ialah 
untuk menggali data secara mendalam yang mungkin hanya bisa didapat dari cara wawancara atau bertanya langsung pada narasumber yang terlibat dalam kegiatan , seperti halnya wawancara kepada Guru di MTs Negeri 2 Kabupaten Cirebon.

Angket dijadikan sebagai teknik pengumpulan data utama selain dokumen, yakni berupa pertanyaan tertulis untuk menghimpun sejumlah keterangan dari sumber data tentang kemampuan penalaran verbal siswa yang dijadikan sampel penelitian. Menurut penjelasan, Sugiyono (2016: 199) menjelaskan bahwa: Kuesioner (Angket) merupakan teknik pengumpulan data yang dilakukan dengan cara memberi seperangkat pertanyaan atau pernyataan tertulis kepada responden untuk dijawabnya.

Instrumen angket digunakan untuk mengetahui Adakah hubungan yang signifikan Pergaulan Teman Sebaya dengan motivasi belajar siswa pada Mata Pelajaran Sejarah Kebudayaan Islam Siswa Kelas VII Di MTs Negeri 2 Kabupaten Cirebon .Soal angket dalam penelitian berupa pernyataan. Jumlah seluruh pernyataan adalah 20 butir pernyataan. Adapun dalam penggunaan angket ini digunakan skala Likert, sebagai berikut :

Tabel 3.5

Skala Likert

\begin{tabular}{|c|c|}
\hline Alternatif Jawaban & Skor \\
\hline Selalu & 4 \\
\hline Sering & 3 \\
\hline Kadang-kadang & 2 \\
\hline Tidak Pernah & 1 \\
\hline
\end{tabular}

\section{Teknik Analisi Data}

\section{Uji Variabel}

Teknik analisis data adalah teknik yang digunakan untuk mengelola data yang dikumpulkan dan diklasifikasikan sesuai dengan tujuan penelitian. Teknik analisis data yang digunakann dalam penelitian ini ialah menganalisis pervariabel 
dengan berpatokan pada buku Suharsimi Arikunto (2006:253), dengan langkahlangkah sebagai berikut:

1. Menghitung rata-rata perindikator

2. Mengkonsultasikan skor butir angket dengan rata-rata indikator ketika skor butir angket di atas rata-rata indikator dinyatakan tinggi, disingkat "T", dan ketika skor butir angket di bawah rata-rata indikator dinyatakan rendah, disingkat " $\mathrm{R}$ "

\section{Uji Korelasi (Product Moment)}

Pada penelitian ini, untuk uji hubungan variabel (corelation) menggunakan korelasi product momment. Korelasi product momment (Product of the momment correlation) adalah salah satu teknik untuk mencari korelasi antar dua variabel yang kerap kali digunakan. Korelasi product momment (KPM) atau sering juga disebut pearson merupakan alat uji statistik yang digunakan untuk menguji hipotesis asosiatif (uji hubungan) dua variabel bila datanya berskala interval atau rasio.

Peneliti menggunakan korelasi product moment karena korelasi tersebut adalah salah satu korelasi yang banyak digunakan dalam penelitian sosial. Dalam penelitian ini, mempunyai dua variabel X dan Y yang mana variabel X (Pergaulan Teman Sebaya) dan Y (Motivasi Belajar).

$$
r x y=\frac{N(\Sigma X Y)-(\Sigma X) \cdot(\Sigma Y)}{\sqrt{\left\{N\left(\Sigma X^{2}\right)-(\Sigma X)^{2}\right\}\left\{N\left(\Sigma Y^{2}\right)-(\Sigma Y)^{2}\right\}}}
$$

Keterangan :

$\mathrm{r}_{\mathrm{xy}} \quad=$ Angka indeks korelasi "r" Product Moment

$\mathrm{N} \quad=$ Jumlah subjek penelitian (Number of Cases)

$\mathrm{XY}=$ Jumlah perkalian skor $\mathrm{X}$ dan skor $\mathrm{Y}$

$\mathrm{X}=$ Jumlah seluruh skor $\mathrm{X}$

$\mathrm{Y} \quad=$ Jumlah seluruh skor $\mathrm{Y}$

Hipotesis diartikan sebagai jawaban sementara terhadap rumusan masalah penelitian.(Sugiono, 2013: 224) Hipotesis merupakan sutau pertanyaan yang penting kedudukannya dalam penelitian. Oleh karena itu, dalam penelitian dituntut untuk merumuskan hipotesis dengan jelas.

Disini peneliti akan melakukan penelitian tentang hubungan antara Antara Pergaulan Teman dengan motivasi Belajar siswa pada mata pelajaran Sejarah 
Kebudayaan Islam Madrasah Tsanawiyah (MTs) Negeri 2 Cirebon. Adapun Hipotesis Statistik sebagai berikut Ha :Adanya hubungan antara Antara Pergaulan Teman dengan motivasi Belajar mata pelajaran Sejarah Kebudayaan Islam Siswa kelas VII Madrasah Tsanawiyah (MTs) Negeri 2 Kabupaten Cirebon. Ho :Tidakadanya hubungan antara Antara Pergaulan Teman dengan motivasi Belajar mata pelajaran Sejarah Kebudayaan Islam Siswa kelas VII Madrasah Tsanawiyah (MTs) Negeri 2 Kabupaten Cirebon Cirebon.

.Berdasarkan hasil perhitungan diatas, diperoleh nilai koefisien Hubungan AntaraPergaulan Teman Sebayadalam meningkatkan Motivasi Belajar mata pelajaran Sejarah Kebudayaan Islam Siswa kelas VII Madrasah Tsanawiyah (MTs) Negeri 2 Kabupaten Cirebon sebesar $r_{x y}=0,31$. Hasil tersebut apabila dirubah kedalam skala konservati, 0,31 berada pada interval 0,20-0,40 yang berarti memiliki tingkat korelasi yang yang lemah atau rendah. Sehingga kita dapat menginterpretasikan yaitu terdapat Hubungan Antara Pergaulan Teman Sebayadalam meningkatkan Motivasi Belajar mata pelajaran Sejarah Kebudayaan Islam Siswa kelas VII Madrasah Tsanawiyah (MTs) Negeri 2 Kabupaten Cirebon.

Berdasarkan perhitungan "r" product moment dihasilkan nilai r sebesar 0,31 kemudian $r$ hitung di atas konsultasikan ke $r$ tabel pada sample sebesar 50 diperoleh $\mathrm{r}$ tabel sebesar 0,284. Dengan begitu dapat dikatakan bahwa $\mathrm{r}$ hitung berada di atas $\mathrm{r}$ tabel, maka uji hipotesis menjawab $\mathrm{H}_{\mathrm{a}}$ diterima dan $\mathrm{H}_{\mathrm{o}}$ ditolak. Artinya bahwa antara variable X (Pergaulan Teman Sebaya) dengan variabel Y (Motivasi Belajar) siswa pada pelajaran SKI Madrasah Tsanawiyah (MTs) Negeri 2Kabupaten Cirebon terdapat hubungan yang signifikan secara statistik.

\section{PENUTUP}

Berdasarkan hasil penelitian tentang Pergaulan Teman Sebayadengan Motivasi Belajar Siswa pada bidang studi Sejarah Kebudayaan Islam Madrasah Tsanawiyah (MTs) Negeri 2 Kabupaten Cirebon yang telah dilakukan dapat disimpulkan ke dalam tiga poin yakni:

Berdasarkan data hasil perhitungan angket dapat peneliti simpulkan bahwa terdapat Pergaulan Teman Sebayapada Mata Pelajaran Sejarah Kebudayaan Islam 
(SKI) di Madrasah Tsanawiyah (MTs) Negeri 2 Kabupaten Cirebon adalah dengan nilai $66,25 \%$ karena berada pada interval $61 \%$ - $80 \%$.dikategorikan Baik.

Berdasarkan data hasil perhitungan angket dapat peneliti simpulkan bahwa terdapat Motivasi Belajar Siswa pada Bidang Studi Sejarah Kebudayaan Islam (SKI) Madrasahdi Madrasah Tsanawiyah (Mts) Negeri 2 Kabupaten Cirebon adalah dengan nilai 74,75\%karena berada pada interval $61 \%$ $\%$.dikategorikan Baik.

Hubungan Pergaulan Teman Sebaya dengan Motivasi Belajar siswa pada bidang studi Sejarah Kebudayaan Islam di Madrasah Tsanawiyah (MTs) Negeri 2Kabupaten Cirebon Kabupaten Cirebon memiliki tingkat korelasi rendah. Hal ini dapat dibuktikan dari perhitungan koefisien korelasi dengan nilai 0,31 yang berada pada interval 0,20-0,40. Pengaruh Pergaulan Teman Sebaya dengan Motivasi Belajar siswa pada bidang studi Sejarah Kebudayaan Islam sebesar 9.61 \% sedangkan sisanya sebesar 90,39\% dipengaruhi oleh faktor lain yang tidak diteliti seperti faktor lingkungan, faktor keluarga, motivasi guru dan lain-lain. Berdasarkan perhitungan uji korelasi " $r$ " product moment dihasilkan nilai $\mathrm{r}_{\text {hitung }}$ 0,284 yang berada di atas $r_{\text {tabel }}$. Artinya semakin baik Pergaulan Teman Sebaya berhubungan dengan tingginya Motivasi Belajar siswa. Demikian pula sebaliknya jika Pergaulan Teman Sebaya yang buruk akan mempengaruhi rendahnya Motivasi Belajar siswa.

\section{DAFTAR PUSTAKA}

Arikunto, Suharsimi, 2014. Prosedur Penelitian Suatu Pendekatan Praktek. Bandung :Rineka Cipta

B. Uno. Hamzah. 2016. Teori Motivasi dan Pengukuranya. Bandung : PT Bumi Aksara.

Dalyono. 2015. Psikologi Pendidikan. Bandung : Rineka Cipta

Djamarah Syaiful Bahri . (2012). Prestasi Belajar dan Kompetensi Guru.Surabaya: UsahaNasional.

Desmita. 2013. Psikologi perkembangan. Bandung :PT remaja rosdakarya 
Eka Izzaty Rita, dkk. 2008. Perkembangan Peserta Didik.Yogyakarta : UNY Press

Fuad Abdul Baqi Muhammad. 2012. Terjemahan Al-Lu'lu wal Marjan Kumpulan Hadist Shahih Bukhari Muslim. Semarang : Pustaka Nuun Hamalik, Oemar. 2014. Psikologi Belajar Mengajar. Bandung : Sinar Baru Algensindo

Hamalik, Oemar. 2017. Proses Belajar Mengajar. Bandung : PT Bumi Aksara Hanafi, 2009. Pembelajaran Sejarah Kebudayaan Islam. Jakarta Pusat:Direktorat Jenderal Pendidikan Islam

Hurlock Elizabeth B 1980. Psikologi Perkembangan Suatu Pendekatan Sepanjang Rentang Kehidupan.Jakarta : Erlangga

Martinis Yamin. 2012. Strategi Pembelajaran Berbasis Kompetensi. Ciputat Referensi (GP press Group)

Mudjiono dan Dimyati. 2015. Belajar dan Pembelajaran. Bandung : Rineka Cipta

Murodi, 2009. Sejarah Kebudayaan Islam. Semarang:PT . Karya Toha Putra

Mustofa Ahmad, 1992. Tafsir Al-Maraghi Juz 25. Semarang : Toha Putra

Nuryati Lusi. 2008. Psikologi Anak. Jakarta : PT Indeks

Partowisastro Koestoer.1983. Dinamika Psikologi Sosial. Jakarta : Erlangga

Purwanto Ngalim. 2014. Psikologi Pendidikan. Bandung :PT Remaja Rosdakarya.

S.L.La Sulo dan. Tirtarahadja Umar. 2005. Pengantar Pendidikan. Bandung : Rineka Cipta

Santrock John W. 2015. Psikologi pendidikan. Jakarta : Prenadamedia Grouf

Sardiman A.M. 2016. Interaksi dan Motivasi Belajar Mengajar. Jakarta : Rajawali Pers

Santosa Slamet. 2009. Dinamika Kelompok. Bandung : PT Bumi Aksara.

Slameto. 2015. Belajar dan Faktor-Faktor Yang Mempengaruhi. Bandung : Rineka Cipta.

Sudijono Anas,. 2010. Pengantar Statistik Pendidikan. Jakarta: Rajawali Press Sugiyono. 2013. Metode Penelitian Pendidikan kuantitatif, kualitatif, $R \& D$. Bandung : Alfabeta 
2016. Metode Penelitian Pendidikan kuantitatif, kualitatif, $R \& D$. Bandung : Alfabeta

Supriyadi Dedi. 2008 Sejarah Kebudayaan Islam. Bandung:Pustaka Setia

Surbakti E. B. 2009. Kenalilah Anak Remaja Anda. Jakarta : Gramedia

Syaikh Shafiyyurrahman Al-Mubarakfuri . 2010. Shahih Tafsir Ibnu Katsir Jilid 8

Jakarta : Pustaka Ibnu Katsir

Taqiyuddin. 2011. Falsafah Dasar Pendidikan Islam Luar Sekolah. Cirebon: CV

PANGGER Publishing

Wina Sanjaya . 2008. Strategi Pembelajaran.. Jakarta: Kencana Prenada

Yusuf Syamsu. 2017 . Psikologi Perkembangan Anak dan Remaja. Bandung :PT

PT Remaja Rosdakarya 